\title{
INTENSIVE FARMING IN THE TE ANAU BASIN
}

\author{
J. H. Paterson \\ Farmer, Te Anau
}

IN APRIL 1962, Southland's first two civilian settlers took up land on the Takitimu Block in the Te Anau Basin. This block is regarded as one of the most favourable in the Basin and its quick response to development now reflects the most concentrated settlement to date. Being one of the first to be settled in this area, I naturally had mixed feelings about the success or failure of farming intensive units in what was commonly regarded as run country, and a cautious approach was required until one became more familiar with the physical and climatic peculiarities of the area. With little to lose and everything to gain, most early settlers set about their tasks with enthusiasm and confidence was gained with the knowledge that these units must prove viable if land settlement were to continue.

The private runholders at this stage gave no lead as their policies were more extensive in scale and not always applicable, and grassland management lagged behind that being practised by the Department, so in most cases the early farmers adjusted their prior experiences to the area. As settlement progressed the basic farming principles most suited to the area were developed with the result that newcomers can now readily obtain information about district practice.

\section{THE EFFECT OF CLIMATE}

This would best be described as very unpredictable, a contention strongly supported by my ten years' experience in this area. So farming here runs headlong into hazard number one the weather.

Rainfall is well distributed and varies from 974 to $1,245 \mathrm{~mm}$ with added effectiveness in the form of overcast or foggy days caused naturally by the proximity of Fiordland and the lakes. In winter and spring there are occasional snowfalls ranging from the blizzard proportions that cause drifting and stock losses, to light, inconvenient falls.

Farmland close to Te Anau has a more favourable climate; snowfalls and frost are not so severe and it is accepted that spring growth is on average a fortnight earlier than in other 
parts of the Basin. Those farming in the perimeter areas of Te Anau expect and allow for snowfalls up to $462 \mathrm{~mm}$ deep and this, if frozen, can persist for periods of three weeks. However, these conditions would prevail only one year in three.

With such winter conditions, one would expect them to be the limiting factor for stock carrying capacities but this is not so. It is the cold northerly or southerly winds during late spring that tend to govern stock rates and it is then that growth can be seriously retarded, resulting in reduced amounts of available grass at the most critical time. However, from now on through summer and autumn, conditions generally improve so that most can justify their reason for farming there. The odd, serious drought is experienced but this has occurred only one year in the last ten. Dry periods occur occasionally and are mostly caused by drying winds rather than the lack of rain, but I welcome these conditions over the autumn as they assist rather than hinder farm management.

\section{INTENSIVE PASTURE MANAGEMENT}

Pasture establishment has always been reliable provided initial requirements of lime and superphosphate are adhered to. Grass sown down following a root crop or on the winter fallow exceeded most expectations during early development. Poor pasture management encouraged grass grub infestation which in turn led to a cocksfoot/white clover dominance and this situation generally remained until the second time over when, with the added fertility build up, better pasture balance was obtained. Where contour and economics allow, the sooner one can achieve this second time over the better, as the area can then be levelled and sown to a ryegrass/white clover pasture which, if managed properly, will produce good quality feed for fattening or hay production. To take advantage of prolific summer and autumn growth, the prudent manager should be closing up areas for hay or lamb fattening in order to achieve maximum growth.

My programme during this period is as follows: Concentrate first on hay, dealing with small areas at a time and not waiting for 250 bales per ha - try for 170 as this will dry quicker, be of better quality, reduce the risk of grass grub, and increase the chances of getting it under cover dry.

Every farmer in this area should have good haymaking machinery and it should be used efficiently in conserving our most necessary and reliable winter supplement. In order to obtain high quality lamb feed, the early hay paddocks should be top- 
dressed immediately to encourage white clover growth. This can be used after a dry or "hardening off" period when clover leaves will wilt during the heat of the day. If this coincides with weaning or a shift of lambs, it provides the best lamb-fattening feed. By programming a series of hay paddocks during the years of plenty, grass growth can be stored in this form and held, if necessary, for two or three years.

Autumn-saved pasture was once accepted as a good way of carrying surplus grass into the winter but here frosts and periods of snow ruin all hopes of conserving good quality feed. Shorter pastures stand up to winter conditions much better as they will not burn off with frost or slush up after snow and will recover sooner with no alteration in grass species. Where farmers practise good grazing procedures on ploughable country, the use of cocks: foot and red clover in pasture mixtures cannot be supported. Both species require lenient grazing and, if saved for hay or winter grazing, they will soon dominate and provide only secondrate feed. Where the site is drier than average, cocksfoot should be included and if on the moist side timothy added, otherwise reliance should be on the ryegrass/white clover mixture.

The following pasture mixture is advocated: Perennial ryegrass, $17 \mathrm{~kg}$; short-rotation ryegrass, $7 \mathrm{~kg}$; white clover, $3.5 \mathrm{~kg}$.

\section{WINTER SUPPLEMENTS}

An optimistic minority would like to think that all-grass farming has its place in the Te Anau Basin and such a practice is undoubtedly most desirable, but is not practicable if using only permanent pasture. To achieve this with confidence, I suggest it can be done only by adopting the following policies:

(1) Conserve as much good hay as possible.

(2) Autumn sow 9 ha of Tama-ryecorn mixture.

(3) Consider early- to mid-October lambing.

(4) Familiarize young stock with hay.

(5) At all times keep pastures under control.

To elaborate further on Tama and ryecorn, I see this combination acting as the safety valve to all-grass farming and prefer to see it used solely for wintering young cattle or failing ewes close to lambing. Most important of all is its ability to survive through winter and still return a high quality feed. If topdressed with $380 \mathrm{~kg}$ of urea in October, the area can be closed at will 
for hay and should yield at least 250 bales per ha of good quality roughage or it can be continually grazed through to sowing down in permanent pasture.

There is no difficulty in growing good crops or swedes or choumoellier and this would still be the most popular feed in the area. To reduce cultivation costs, the tendency today is to concentrate on reduced areas well prepared to yield high quantities of weed-free crops. Where the nature of the property prohibits economic cultivation for root crops, grain feeding has proved a good substitute, and ground conditions on these stony areas allow good use of this concentrated form of feeding. Of the systems in vogue, I first favour full utilization of the grass available, supported by quantities of fodder or grain in relation to each farm's stage of development. As pastures improve, I see increases in the amount of hay being saved and a reduction in the area of root crops sown, but whatever system is implemented one should always allow for the unexpected and be able to provide some alternative supplement should weather interrupt the accepted practice.

\section{STOCKING POLICIES}

Because of the climate, farmers in the Basin are almost committed to grassland farming. Grain growing is unreliable and out-of-season frosts deter most who might consider small seeds as a diversity. After settlement all units are of a standard well able to support fattening or breeding policies. Variable stock performances, particularly lambing percentages, have always caused concern, and most would agree there is ample room for improvement. Discounting losses attributable to weather, I would estimate most settlers to average a little better than $100 \%$ lambing with some doing as high as $130 \%$ in favourable years.

Early development revealed the need to use selenium as a means of reducing dry ewes, scientific information warned us against using red and white clover prior to tupping, and the weather frequently reminds us of the damage it can do. Yet many seem to do little to correct this serious situation. For example, the Department of Lands and Survey with 135,000 ewes at stake would need only $5 \%$ lambing increase to produce 6,750 extra lambs and, valued at $\$ 5$, that would represent an increased earning of $\$ 33,750$.

All this could be gained for very little extra cost. Having experimented with lambing dates from end of August to mid- 
October, I am convinced most farmers and the Department are still too early and list the following advantages with later lambing:

(1) Greater daylight hours coupled with higher temperatures.

(2) More available grass reduces the risk of a milk check.

(3) A quicker lamb drop.

(4) Better utilization of the pattern of grass growth.

(5) Similar lambing dates for ewes and hoggets allow mothering on if desired.

(6) Reduced risk of sleepy sickness and milk fever, meaning fewer deaths.

(7) An opportunity is allowed to sow down young grass before lambing.

To avoid unnecessary worry one must consider the overall picture and be prepared to adjust lambing in relation to grass growth.

Management is simple if there is available grass during lambing but very complex if there is not, so a trial over a period of years is well worth while.

Should the meat trade offer an incentive to produce heavy lamb, this area seems to be one of the best suited for the purpose.

Only then will the situation arise where a quality article is being produced that fully utilizes the growth pattern and also helps spread the lamb kill, This all reverts back to climate; it cannot be changed, so it is necessary to apply the management most suited to it, and if the article produced commands a fair price, then what more could be asked by the farmer?

Cattle policies in the Basin vary from sophisticated breeding techniques to simple fattening. Both have a place and both methods are on the increase, with most farmers choosing the one most suited to their particular stage of development.

\section{TOPDRESSIN G}

The Department and established farmers would be the first to admit that topdressing has been the key to successful development in the Basin. The response from heavier than average applications amazed most and possibly set a foundation that most private and settled farmers now accept as a routine recipe for optimum grass growth. With the large amounts required, one must not overlook the assistance of the Government subsidy 
scheme on cartage and the active co-operation of the Southland works. Both have made possible the use of our most important limiting factor, with the result that today most farmers are using about $380 \mathrm{~kg}$ of superphosphate/ha as maintenance on good grassland. Variable quantities and mixtures are used with hay and root crops and I am in no position to advise on what I consider to be an individual's choice for a particular need. I choose spring applications as most convenient and rewarding and now use a more balanced mixture and include periodic additions of cobalt and bluestone rather as an insurance than for visible worth. Present basic topdressing is $380 \mathrm{~kg}$ of turnip, rape and grain mixtures per ha costing \$26.27 per tonne in bulk from a 1-6-5 element count.

\section{CONCLUSIONS}

Because of the unpredictable weather, farming in the Te Anau Basin is limited to sheep and cattle. Although winters are often long and severe, ground conditions for wintering stock are very good. Transport costs to and from the farm are high.

Given reasonable costs and prices, those settled to date have proved that farming here is viable and, in the interests of New Zealand and Te Anau, settlement should be resumed as soon as possible. As long as tourism and farming remain harmonious, Te Anau has a great future. 